\title{
Essential Oil Composition and Antimicrobial Activity of Artemisia herba - alba Asso Grown in Algeria
}

Samah Lakehal*, Meliani A, Benmimoune S, Bensouna SN, Benrebiha FZ and Chaouia C

Laboratory of Biotechnology Plants Production, Department of Biotechnology, Blidal University, Blida, Algeria

\begin{abstract}
In the recent decades, antimicrobial plant products have gained special interest because of the resistance to antibiotics that some micro-organisms have acquired. Aromatic and medicinal plants are an important source of bioactive molecules, especially in volatile extracts, that are considered among the most important antimicrobial agents present in these plants. Volatile components of Artemisia herba-alba Asso essential oil obtained by hydrodistillation growing in Algeria (Djelfacityof south Algeria) were investigated by GC/FID and GC-MS. The major components were found to be camphor (39.5\%), chrysanthenone (10.38\%), 1,8-cineole (8.6\%), $\alpha$-thujone (7.03\%), Borneol $(3.35 \%)$ and bornyl acetate $(2.52 \%)$. The essential oil has been tested for antimicrobial activity against Gram-negative and Gram-positive bacteria. Inhibition of growth was tested by the agar diffusion method. The Minimal Inhibitory Concentration (MIC) was determined by the method of agar dilution.
\end{abstract}

Keywords: Artemisia herba-alba Asso; Essential oil; Camphor; Antimicrobial activity

\section{Introduction}

In the last few years, due to the misuse of antibiotics and an increasing incidence of immunodeficiency-related diseases, the development of microbial drug resistance has become more and more of a pressing problem [1]. Recently, natural products from aromatic and medicinal plants represent a fertile ground for the development of novel antibacterial agents [2]. Plants essential oils have come more into the focus of phytomedicine [2,3]. It is important to develop a better understanding in basic research applications, especially, of the anti-microbial activity of essential oils [4]. The Mediterranean region is relatively rich with plants (between 15,000 and 20,000 species). Algeria, a North African country with a large variety of soils (littoral, steppe, mountains and desert) and climates, possesses a rich flora (more than 3,000 species and 1,000 genders) [5].

In this context and in order to enhance our diverse and rich national heritage, we are interested in the study of Artemisia herbaalba Asso greenish-silver perennial herb, grows 20 to $40 \mathrm{~cm}$ in height and belongs to the daisy family Asteraceae [6]. In Algeria, this plant commonly known as the white wormwood in Arabic as "Chih" and in France as "Armoisebalnche" [7], is one of five spontaneous Artemisia species that were identified [8] and was used as aromatisant for tea. It has been used in folk medicine by many cultures since ancient times, to treat colds, coughing, bronchitis, intestinal disturbances, diarrhea, neuralgias arterial hypertension and/or diabetes [9-11]. Many researchers have reported various biological and/or pharmacological activities of Artemisia herba-alba Asso essential oil as an antimicrobial, antioxidant, antidiabetic, Antileishmanial, anthelmintic and antispasmodic agent [6,12-16].

The aim of the present investigation was to study the antibacterial effect of Artemisia herba-alba Asso essential oil on different bacterial species. This was done through tow techniques: the agar diffusion assay as well as the agar dilution method was used for determination of Minimum Inhibitory Concentration (MIC). In addition, the compositions of volatile compounds were determined to use these data to deduce which components are likely to contribute to the activities of the whole oils and to determine any structural relationships between the components and their antibacterial activity.

\section{Materials and Methods}

\section{Plant material}

The aerial parts of Artemisia herba-alba Asso were collected on April 2013 from Djelfa, region with a semi- arid climate, located right in the heart of the steppe zone, $300 \mathrm{~km}$ south of Algiers. It is the last town before the Saharan Atlas and the desert. (Coordinates: Latitude $33^{\circ}-35^{\circ} \mathrm{N}$, longitude $2^{\circ}-5^{\circ} \mathrm{E}$ ). After been harvested, the fresh vegetable matter was first weighted and then dried on the shadow, until weight stability. Then the leaves were separated from stems.

\section{Essential oil extraction}

Air-dried leaves and flowers were submitted to hydro distillation for $3 \mathrm{~h}$, using a Clevenger type apparatus [17], according to the European Pharmacopoeia [18]. The oil yield was expressed v/w vs. dry matter. The essential oil was dried over anhydrous sodium sulphate, filtered and stored in a sealed vial in the dark at $+4^{\circ} \mathrm{C}$ before analysis and bioassays tests.

\section{Mass spectrometry analysis}

The oil was analyzed by Gas Chromatography-Mass Spectrometry (GC-MS) using a Hewlett Packard 6890 mass selective detector coupled with a Hewlett Packard 6890 gas chromatograph equipped with a $30 \mathrm{~m}$ $\times 0.25 \mathrm{~mm}$ HP-5 (cross-linked Phenyl-Methyl Siloxane) column with $0.25 \mu \mathrm{m}$ film thickness (Agilent), Helium was used as carrier gas, the flow through the column was $1.4 \mathrm{ml} / \mathrm{min}$, and the split less mode was used. The column temperature was programmed from 35 to $85^{\circ} \mathrm{C}$ at $20^{\circ} \mathrm{C} / \mathrm{min}$, increased from 85 to $300^{\circ} \mathrm{C}$ at rate of $5^{\circ} \mathrm{C} / \mathrm{min}$ and finally held for $10 \mathrm{~min}$.

*Corresponding author: Samah Lakehal, Laboratory of Biotechnology Plants Production, Department of Biotechnology, Blidal University, Blida, Algeria, Tel: 00213697016695; E-mail: laksam@hotmail.fr

Received June 21, 2016; Accepted June 25, 2016; Published June 30, 2016

Citation: Lakehal S, Meliani A, Benmimoune S, Bensouna SN, Benrebiha FZ, et al (2016) Essential Oil Composition and Antimicrobial Activity of Artemisia herba-alba Asso Grown in Algeria. Med chem (Los Angeles) 6: 435-439. doi:10.4172/21610444.1000382

Copyright: ( 2016 Lakehal S, et al. This is an open-access article distributed under the terms of the Creative Commons Attribution License, which permits unrestricted use, distribution, and reproduction in any medium, provided the original author and source are credited. 
The MS operating parameters were as follows: ionization potential, $70 \mathrm{eV}$; ionization current, $2 \mathrm{~A}$; ion source temperature, $200^{\circ} \mathrm{C}$, resolution, 1000. Mass unit were monitored from 30 to $450 \mathrm{~m} / \mathrm{z}$. Identification of components in the oil was based on retention indices relatives to n-alkanes and computer matching with the WILLEY 275.L library, as well as by comparison of the fragmentation patterns of mass spectra with those reported in the literature Adams.

\section{Antimicrobial activity}

The essential oils were individually tested against Gram positive bacteria and Gram negative bacteria. Bacterial strains used in this study were obtained from American Type Culture Collection (ATCC), USA: Pseudomonas aeruginosa ATCC12228, Staphylococcus aureus ATCC 25923, Klebsiella pneumoniae (ATCC 13883), Bacillus cereus (ATCC, 11778) and Escherichia coli ATCC125922.

\section{Antibacterial screening}

Two techniques were used to test the microbial activity of Artmisiaherba-alba Asso:

Agar diffusion method: Antibacterial activities of Artmisiaherbaalba Asso essential oil were assessed using the paper disk agar diffusion method according to Imelouane et al. [19] with some modifications. A 16-h culture was diluted with sterile physiological saline solution with reference to the MC Farland 0.5 standard to achieve an inoculum of approximately $10^{6} \mathrm{CFU} / \mathrm{ml}$. A suspension was swabbed in three directions on $4 \mathrm{~mm}$ thick Mueller Hinton agar (MHA). Absorbent disk (Whatman disk $\mathrm{N}^{\circ}$. 4 of $6 \mathrm{~mm}$ diameter) containing $15 \mu \mathrm{l}$ of filter sterilized test essential oil were applied on the surface of the plate $(90$ $\mathrm{mm}$ ) inoculated with different microbial strains. The plates were then incubated for $24 \mathrm{~h}$ at $37^{\circ} \mathrm{C}$. Negative control was prepared using a disk impregnated with sterile water. Finally, antimicrobial activity was evaluated by measuring the diameter $(\mathrm{mm})$ of the growth inhibition zones including the $6 \mathrm{~mm}$ disk. The measurements of inhibition zones were carried out for three sample replications.

Agar dilution method: The Minimum Inhibitory Concentration (MIC) of the tested essential oil was determined using the agar dilution method approved by Bansod and Rai [20] with the following modification: Tween-80 was incorporated into the agar after autoclaving to enhance oil solubility. Briefly, Petri plates containing various concentrations of essential oil 0.003 to $2.5 \%(\mathrm{v} / \mathrm{v})$ were inoculated with each tested strain. Plates were dried at $35^{\circ} \mathrm{C}$ prior to inoculation with 1-2 $\mathrm{ml}$ spots containing approximately $10^{5} \mathrm{CFU}$ of each organism. Un-inoculated plates containing essential oil served as negative control. Tween- 80 was used as a positive growth control. Test and control plates were then incubated for $24 \mathrm{~h}$ for pathogenic bacterial strains at $37^{\circ} \mathrm{C}$. Plates were evaluated for the presence or the absence of colonies after incubation. For each treatment, the absence of colonies on all plates tested was considered as an inhibitory effect. The lowest concentration of essential oil required to completely inhibit the growth of the tested microorganism was designated as the MIC [21].

\section{Results and Discussion}

Hydro distillation of the leaves of Artemisia herba-alba Asso yielded yellow liquid oil with a strong penetrating pleasant herbaceous odor characteristic of the plant. The oil yield was $0.8 \%$. The chemical composition of the oil was investigated using GC/ FID and GC/MS techniques. The percentages and the retention indices of the identified components are listed in Table 1 in the order of their elution on the HP$5 \mathrm{MS}$ column. From the data obtained, 31 compounds were identified, representing $92.84 \%$ of the oil.

\begin{tabular}{|c|c|c|}
\hline $\mathbf{R I}$ & Compound & $\%$ \\
\hline 934 & a-pinene & 1,16 \\
\hline 950 & Camphene & 6,00 \\
\hline 974 & Sabinene & 0,90 \\
\hline 990 & 1-octen-3-ol & 0,27 \\
\hline 1017 & a-terpipene & 0,26 \\
\hline 1025 & para-Cymene & 0,48 \\
\hline 1033 & 1,8-cineole & 8,60 \\
\hline 1058 & $\mathrm{Y}$-Terpinene & 0,30 \\
\hline 1074 & a-thujone & 7,03 \\
\hline 1091 & $\alpha$-Terpinolene & 0,26 \\
\hline 1107 & Filifolone & 1,04 \\
\hline 1119 & $\beta$-Thujone & 1,74 \\
\hline 1124 & Chrysanthenone & 10,38 \\
\hline 1153 & Camphre & 37,50 \\
\hline 1156 & Sabina ketone & 1,07 \\
\hline 1162 & Pinocarvone & 1,79 \\
\hline 1169 & Borneol & 3,35 \\
\hline 1178 & Terpinene-4-ol & 1,07 \\
\hline 1206 & Verbenone & 0,23 \\
\hline 1229 & Cis-carveol & 0,25 \\
\hline 1237 & E-ocimenone & 0,34 \\
\hline 1244 & Carvone & 0,15 \\
\hline 1275 & Bornylacetate & 2,52 \\
\hline 1287 & Carvacrol & 0,70 \\
\hline 1298 & Y- Elemene & 0,12 \\
\hline 1313 & Bicycloelemene & 0,17 \\
\hline 1393 & Germacrene D & 1,07 \\
\hline 1418 & Germacrene B & 0,55 \\
\hline 1444 & Bicyclo- germacrène & 0,33 \\
\hline 1457 & Delta-cadinene & 0,22 \\
\hline \multirow[t]{5}{*}{1465} & Spathulenol & 1,31 \\
\hline & Oxygenatedmonoterpenes & 77,78 \\
\hline & Monoterpenehydrocarbons & 11,29 \\
\hline & Sesquiterpeneshydrocarbons & 3,77 \\
\hline & Total & 92,84 \\
\hline
\end{tabular}

RI: Retention indices calculated against n-alkanes on the HP 5MS column Compounds are listed in order of their elution from a HP 5MS column. $\%$ Percentages obtained by FID peak-area normalization.

Table 1: Chemical Composition of Artemisia herba-alba Asso essential oil.

The chemical classes' distributions of Artemisia herba alba Asso essential oil could be separated into three classes (Table 1). These were monoterpene hydrocarbons, oxygenated monoterpenes, sesquiterpene hydrocarbons, and others. Monoterpenes represented about $89.07 \%$ of the total essential oil constituents. Oxygenated monoterpenes constituted the main chemical class of the oil (77.78\%) and they were represented by camphor (39.5\%), chrysanthenone (10.38\%) 1,8-cineole (8.6\%), a-thujone (7.03\%), borneol (3.35\%) and bornyl acetate $(2.52 \%)$ as the principal components.

Moreover, monoterpene hydrocarbons were represented by $11.29 \%$ of all the oil. Among these compounds, Camphene (6.0\%), $\alpha$-pinene $(1.45 \%)$ and $\rho$-cymene $(0.48 \%)$ were the most important. Sesquiterpenes constituted $3.77 \%$ of all the oil germacrene D (1.07\%) and spathulenol (1.31\%) were the main ones.

For further comparison, the composition of A. herba alba essential oil dominated by Camphor was found in Morocco (Taforalt, Machraa) [19,22], Algeria (Méchrea, Nord sahara, M’sila, Djelfa, Bejiai, Saida) [23-29] and Iraq (Karbala desert) [30].

$\alpha$-thujone little present in our essential oils with $7.03 \%$, it is the major component of the essential oil of Tunisia (BirElhfay) [6] and Jordan [31]. 
Similarly, Boukrich et al. [32] have shown that $\alpha$-thujone is the main compound of wormwood from semi-arid and arid areas of Tunisia.

According Akrout et al. [33] and Mighri et al. [13], the essential oil of wormwood from the Beni- Khedache region (southern Tunisia) and the region of Kirchaou (southeast Tunisia) is characterized by the dominance of $\beta$-thujone. Moreover Zaim et al. [34] showed that the essential oil of Artemisia herba-alba Asso. South of Morocco (Ouarzazate) contains chrysanthenone as major compound. Cischrysanthenyl acetate was found to be the major component in some oils from Tunisia (Gafsa) and Algeria (Biskra) [35,36] (Table 1). Davanon was reported as constituting major in the essential oil of some chemo types of Spain and Algerian (Djelfa) species [37,38].

Similarly, Dahmani-Hamzaoui and Baaliouamer [39] identified the davanon in the essential oil of sagebrush Djelfa. Tilaoui et al. [40] showed that the oil sagebrush of Imilchil ErRachidia (Morocco) contains the verbenol as major compound. The eucalyptol is identified as the major constituent in the essential sagebrush oil from southern Spain $(41 \%$ maximum) [37] and Egypt [41]. The chemical composition of Artemisia herba-alba Asso essential oils shows a large interspecies variability and, within the same species. Various compositions dominated either by a single component ( $\alpha$-thujone, camphor, chrysanthenone or transsabinyl acetate) or characterized by the occurrence, of two or more of these compounds at appreciable contents [32].

Chemical variability of Artemisia herba-alba Asso seems to depend on the genetic characteristics of the plant [42], geographical locations, consequently different climatic conditions under which it has grown $[13,24]$, part of the plant, stadephénologique, and the method used to obtain the essential oil [43-46]. In fact, these factors influence the plant's biosynthetic pathways and, consequently, the relative proportion of the main characteristic compounds [47]. The in vitro antimicrobial activity of Artemisia herba-alba Asso essential oil against the microorganisms employed and its activity potentials were qualitatively and quantitatively assessed by the presence or absence of inhibition zones, zone diameters and MIC values. Table 2 reports the inhibition zone of essential oil determined for 24 of Gram positive or Gram negative bacteria using the diffusion technique on solid media.

The data shows that this oil had variable antimicrobial activity against all tested strains. The inhibition zones were in the range of 15-33 mm. Gram positive bacteria were shown to be more sensitive to the Artemisia herba-alba Asso essential oil. The data indicated that Gram-positive S. aureus was the most sensitive strain tested to the oil of Artemisia herba-alba Asso with the strongest inhibition zone (33.00 \pm $0.45 \mathrm{~mm}$ ). Among these, Gram-negative strains also displayed variable degree of susceptibility against investigated oil. Maximum activity was $E$. coli $(19.00 \pm 0.55)$. Modest activities were observed against $K$. pneumoniae, with inhibition zones of $(15 \pm 0.54 \mathrm{~mm})$ (Table 2).

$P$. aeruginosa was considered resistant since no inhibition zone was observed. It is known to have high level of intrinsic resistance to virtually all known antimicrobials and antibiotics due to a combination of a very restrictive outer membrane barrier which is highly resistant even to synthetic drugs. The in vitro activity of Artemisia herba-alba Asso essential oil was evaluated by a broth micro dilution method using a panel of micro-organisms. Antimicrobial activity was expressed as Minimum Inhibitory Concentration (MIC). The results of the MIC are in Table 3. The data indicate that the oil exhibited varying levels of antimicrobial activity against the investigated food pathogens. The inhibitory properties of the oil were observed within a range of concentrations from 0.1 to $21.00 \mathrm{mg} / \mathrm{ml}$. The essential oil was active against all the test strains. The Gram-negative $P$. aeruginosa seemed to be resistant to the investigated oil with a MIC of $21.00 \mathrm{mg} / \mathrm{ml}$.

\begin{tabular}{|c|c|}
\hline Microorganisms & ZI (mm) \\
\hline Klebsiella pneumoniae & $15 \pm 0.54$ \\
\hline Pseudomonas aeruginosa & $06 \pm 00$ \\
\hline Escherichia coli & $19 \pm 0.55$ \\
\hline Bacillus cereus & $21 \pm 0.43$ \\
\hline Staphylococcus aureus & $33 \pm 0.43$ \\
\hline
\end{tabular}

Zl: Essential oil zone inhibition

Data are presented as mean values \pm SD

Table 2: Antibacterial activity of essential oil as determined by diffusion technique on solid media.

\begin{tabular}{|c|c|}
\hline Microorganisms & MIC $\mathbf{( m g / m l})^{*}$ \\
\hline Klebsiella pneumoniae & $0.84 \pm 0.01$ \\
\hline Pseudomonas aeruginosa & $21 \pm 0.01$ \\
\hline Escherichia coli & $0.84 \pm 0.01$ \\
\hline Staphylococcus aureus & $0.1 \pm 0.01$ \\
\hline
\end{tabular}

*Data are presented as mean values \pm SD

MIC: Minimal Inhibitory Concentration.

Table 3: Minimal inhibitory concentration (MIC) of essential oil from Artemisia herba-alba Asso.

Maximum activity was observed against $S$. aureus with MIC of $0.1 \mathrm{mg} / \mathrm{ml}$ to the oil. The essential oil was evaluated for antimicrobial activity against pathogenic strains of Gram positive (S. aureus) and Gram negative (E. coli, P. aeruginosa, K. pneumoniae) bacteria (Tables 2 and 3). It was found to be active against all the bacterial strains except for $P$. aeruginosa (no inhibition zone was observed). The essential oils evaluated in this work have a great variety of phytochemicals that could be considered as responsible for a larger or smaller part of the antimicrobial activity. The antimicrobial activity of Artemisia herbaalba Asso essential oil would be related to its oxygenated monoterpenes components [35] which constitute about $77.78 \%$ of the oil.

Research into the antimicrobial actions of monoterpenes suggests that they diffuse into and damage cell membrane structures [48].

Indeed, in essential oils, it was shown that monoterpenes hydrocarbons and oxygenated monoterpenes in essential oils are able to destroy cellular integrity resulting in respiration inhibition and permeability alteration [49]. Besides, the most abundant component in essential oil of A. herba alba, camphor, has been reported to exhibit bacteriostatic activity against $P$. aeruginosa [19], and this compound is a major constituent in a number of antibacterial essential oils [50,51]. The major components of Artemisia herba-alba Asso essential oils, such as the monoterpenoids thujone, camphor, 1-8 cineole, camphene, are known for their potential antimicrobial properties against both gram-positive and gram-negative bacteria [52-54]

In addition, other minor components such as borneol (4.88\%) have been also reported to have antimicrobial potential [13]. In other studies, a-pinene, has been known to exhibit antimicrobial activity against the bacterial strains (E. coli, P. aeruginosa, S. aureus, bacillussubtilis) [1]. In fact, the biological effectiveness of essential oil is related to their different chemical constituents (major, minor and their mutual ratios) acting either synergistically or antagonistically with major components $[55,56]$. In general, the antimicrobial activity of the essential oils tested was more pronounced against Gram-positive than against Gramnegative bacteria [57].

This generally higher resistance among Gram-negative bacteria, According to Lambert [58], Harris [59] and Bezic et al. [60], could be ascribed to the structure of the cell wall of gram-negative bacteria primarily made up of a lipopolysaccharide that blocks the penetration of hydrophobic compounds and prevents the accumulation of essential oils in the membrane of target cells. The absence of this barrier in Gram- 
positive bacteria allows the direct contact of the essential oils hydrophobic constituents with the phospholipid bilayer of her cell membrane, where they bring about their effect, causing either an increase of ion permeability and leakage of vital intracellular constituents, or impairment of the bacterial enzyme systems [61,62] (Table 3).

Although the antibacterial activity of essential oils from many plant species has been extensively surveyed, their antimicrobial mechanism has not been reported in great detail. Since the active antimicrobial compounds of essential oils are phenolics and terpenes, it seems reasonable that their mode of action might be similar to that of other phenolic compounds. According to Burt [63], given the large number of different groups of compounds present in essential oils, the antibacterial activity of essential oil is most likely not attributable to a specific mechanism but to several mechanisms related to various targets in the cell.

Most of the studies on the mechanism of phenolic compounds focused on their effects on cellular membranes, altering its response to antimicrobial challenge. These effects may develop as a result of membrane depolarization by altered ion transport or through changes in the membrane structure, inhibition of energy (ATP) generation by interference with glucose uptake or inhibition of enzymes involved in oxidative or substrate level phosphorylation. Increases in cytoplasmic membrane permeability appear to be a consequence of the loss of the cellular $\mathrm{pH}$ gradient, decreased ATP levels and, loss of the proton motive force, which lead to cell death [64].

The antimicrobial activity and, consequently, the minimum inhibitory concentration of essential oils can be influenced by the growing region of the plant, the extraction method used, the plant part used (leaf or whole plant), the method of preparation of the raw material (fresh or dry), the type of organism, the cultivation conditions (incubation time, temperature, oxygen), the culture medium, the concentration of the test substance and the solvents used to dilute the oil, among other factors [63,65-71].

\section{Conclusions}

The composition of the essential oil of Artemisia herba-alba Asso growing in Algeria has been analyzed and its antimicrobial activity investigated. The results indicate that the oil may be used in the treatment of diseases caused by the micro-organisms tested. Further toxicological and clinical studies are required to prove the safety of the oil as a medicine.

\section{References}

1. Wang W, Li N, Luo M, Zu Y, Efferth T (2012) Antibacterial activity and anticancer activity of Rosmarinus officinalis L. essential oil compared to that of its main components. Molecules 17: 2704-2713.

2. Zu Y, Yu H, Liang L, Fu Y, Efferth T, et al. (2010) Activities of ten essential oils towards Propionibacterium acnes and PC-3, A-549 and MCF-7 cancer cells. Molecules 15: 3200-3210.

3. Sylvestre M, Pichette A, Longtin A, Nagau F, Legault J (2006) Essential oil analysis and anticancer activity of leaf essential oil of Croton flavens L. from Guadeloupe. J Ethnopharmacol 103: 99-102.

4. Mimica-Dukic N, Bozin B, Sokovic M, Simin N (2004) Antimicrobial and antioxidant activities of Melissa officinalis L. (Lamiaceae) essential oil. J Agric Food Chem 52: 2485-2489.

5. Veesenmeyer JL, Hauser AR, Lisboa T, Rello J (2009) Pseudomonas aeruginosa virulence and therapy: evolving translational strategies. Crit Care Med 37: 1777-1786.

6. Kadri A, Ben Chobba I, Zarai Z, Békir A, Néji G, et al. (2011) Chemical constituents and antioxidant activity of the essential oil from aerial parts of Artemisia herba-alba grown in Tunisian semi-arid region. Afr J Biotechnol 10: 2923-2929.
7. Segal R, Feuerstein I, Danin A (1987) Chemotypes of Artemisia herba alba in Israel based on their sesquiterpene lactone and essential oil constitution. Phytochem 15: 411-416.

8. Nabli MA (1989) Elements of botany and phyto-ecology (in French). Faculty of Sciences of Tunis, Official printing office of the Tunisian Republic, Tunisia.

9. Jouad H, Haloui M, Rhiouani H, El Hilaly J, Eddouks M (2001) Ethnobotanical survey of medicinal plants used for the treatment of diabetes, cardiac and renal diseases in the North centre region of Morocco (Fez-Boulemane). J Ethnopharmacol 77: 175-182.

10. Tahraoui A, El-Hilaly J, Israili ZH, Lyoussi B (2007) Ethnopharmacological survey of plants used in the traditional treatment of hypertension and diabetes in southeastern Morocco (Errachidia province). J Ethnopharmacol 110: 105-117.

11. Zeggwagh NA, Jean Baptiste M, Eddouks M (2014) Acute hypotensive and diuretic activities of Artemisia herba alba aqueous extract in normal rats. Asian Pac J Trop Biomed 4: S644-S648.

12. Iriadam MD, Musa GM, Hatice $H$, Sun Baba F (2006) Effects of two Turkish medicinal plants Artemisia herba-alba and Teucrium polium on blood glucose levels and other biochemical parameters in rabbits. J Cell Mol Biol 5: 19-24.

13. Mighri $H$, Hajlaoui $H$, Akrout A, Najjaa H, Neffati M (2010) Antimicrobial and antioxidant activities of Artemisia herba-alba essential oil cultivated in Tunisian arid zone. Comptes Rendus Chimie 13: 380-386.

14. Essid R, Rahali FZ, Msaada K, Sghair I, Hammami M, et al. (2015) Antileishmanial and cytotoxic potential of essential oils from medicinal plants in Northern Tunisia. Ind Crops Prod 77: 795-802.

15. Hatimi S, Boudouma M, Bichichi M, Chaib N, Idrissi NG (2001) In vitro evaluation of antileishmania activity of Artemisia herba alba Asso. Bull Soc Pathol Exot 94: 29-31.

16. Yashphe J, Feuerstein I, Barel S, Segal R (1987) The Antibacterial and Antispasmodic Activity of Artemisia herba alba Asso. II. Examination of Essential Oils from various Chemotypes. Int J Crude Drug Res 25: 89-96.

17. Clevenger JF (1928) Apparatus for the determination of volatile oil. J Am Pharm Assoc 17: 341-346.

18. European Pharmacopoeia (2008) Huiles essentielles. Aetherolea 1: 2098.

19. Imelouane B, El Bachiri A, Ankit M, Khedid K, Wathelet JP, et al. (2010) Essential oil Composition and antimicrobial Activity of Artemisia Herba-Alba Asso Grown in Morroco. Banats J Biotechnol 1: 48-55.

20. Bansod S, Rai M (2008) Antifungal Activity of Essential Oils from Indian Medicinal Plants Against Human Pathogenic Aspergillus fumigatus and $A$. niger. World J Med Sci 3: 81-88.

21. Selim S (2011) Antimicrobial activity of essential oils against vancomycinresistant enterococci (vre) and Escherichia coli 0157:h7 in feta soft cheese and minced beef meat. Braz J Microbiol 42: 187-196.

22. Paolini J, El Ouariachi EM, Bouyanzer A, Hammouti B, Desjobert JM, et al (2010) Chemical variability of Artemisia herba alba Asso essential oils from East Morocco. Chemical Papers 64: 550-556.

23. Houmani M, Houmani Z, Melpomeni S (2004) Intérêt de Artemisia herba alba Asso dans l'alimentation du bétail des steppes algériennes. Acta Bot Gall 151: 165-172.

24. Belhattab R, Loubna A, José G, Barroso LG, Pedro A, et al. (2014) Essential oil from Artemisia herba-alba Asso grown wild in Algeria: Variability assessment and comparison with an updated literature survey. Arabian Journal of Chemistry 7: 243-251.

25. Tani ZB, Bendahou M, Khelil MA (2010) Lutte contre la bruche acanthoscelidesobtectus et la mite tineolabisselliella par les huiles essentielles extraites de deux plantes aromatiques d'Algerie'. Lebanese Sci J 11: 55-68.

26. Dahmani-Hamzaoui N, Baaliouamer A (2010) Chemical composition of Algerian Artemisia herba-alba essential oils isolated by microwave and hydrodistillation. JEOR 22: 514-517.

27. Dob T, Ben Abdelkader T (2006) Chemical composition of the essential oil of Artemisia herba-alba Asso grown in Algeria. JEOR 18: 685-690.

28. Maiza-Benabdesselam F, Bekka F, Touati A, Gören AC, Benallaoua S (2011) Antibacterial activity of essential oils of two Algerian medicinal plants: Origanum glandulosum Desf. and Artemisia herba alba asso. Life Sciences Leaflets 16: 583-594.

29. Bouzidi N, Mederbal K, Raho GB (2016) Antioxidant Activity of Essential Oil of Artemisia herba alba. J Appl Environ Biol Sci 6: 59-65. 
30. Abaas IS, Hamzah JM, Ali HM (2013) Analysis with evaluation of drying temperature on essential oil content of Achillea Frayrantissima L. and Artemisia herb-alba Asso. Int J Pharm Pharm Sci 5: 913-914.

31. Hudaib MM, Aburjai TA (2006) Composition of the essential oil from Artemisia herba-alba grown in Jordan. JEOR 18: 301-304.

32. Boukrich F, Zouari S, Neffati M, Abdelly C, Liu K, et al. (2009) Chemical variability of Artemisia herba-alba Asso growing wild in Semi-arid and Arid Land (Tunisia). JEOR 22: 331-335.

33. Akrout A, AL Jani $H$, Amouri S, Neffati M (2010) Screening of antiradical and antibacterial activities of essential oils of Artemisia campestris L., Artemisia herba-alba Asso, and Thymus capitatus Hoff. Et Link. Growing wild in the southern of Tunisia. Rec Res Sci Tech 2: 29-39.

34. Zaim A, Lahsen E, Abdellah F (2012) Effets des huiles essentielles d'Artemisia herba-alba sur la survie des criquets adultes d'Euchorthippus albolineatus (Lucas, 1849). Bulletin de l'Institut Scientifique, Rabat, section Sciences de la Vie 34: 127-133.

35. Zouari S, Zouari N, Fakhfakh N, Bougatef A, Ayadi MA, et al. (2010) Chemical composition and biological activities of a new essential oil chemotype of Tunisian Artemisia herba alba Asso. J Med Plant Res 4: 871-880.

36. Bezza L, Mannarino A, Fattarsi K, Mikail C, Abou L, et al. (2010) Chemical composition of the essential oil of Artemisia herba-alba issued from the district of Biskra (Algeria). Phytothérapie 8: 277-281.

37. Salido S, Valenzuela LR, Altarejos J, Nogueras M, Sanchez A, et al. (2004) Composition and infraspecific variability of Artemisia herba alba from southern Spain. Biochem Syst Ecol 32: 265-277.

38. Salido S, Altarejos J, Nogueras M, Sánchez A (2001) Chemical composition of the essential oil of Artemisia herba-alba Asso ssp. valentina (Lam.) Marcl. JEOR 13: 221-224.

39. Dahmani-Hamzani N, Baaliouamer A (2005) Chemical composition of the Algerian essential oil of Artemisia herba-alba native to Dejelfa. Riv Ital EPPOS 40.

40. Tilaoui M, Ait Mouse H, Jaafari A, Aboufatima R, Chait A, et al. (2011) Chemical composition and antiproliferative activity of essential oil from aerial parts of a medicinal herb Artemisia herba alba. Rev. Bras. Farmacogn 21: 781-785.

41. Mohamed AEH, El-Sayed MA, Hegazy ME, Helaly SE, Esmail AM, et al. (2010) Chemical Constituents and Biological Activities of Artemisia herba-alba. Rec Nat Prod 4: 1-25.

42. Skoula M, EI Hilali I, Makris AM (1999) Evaluation of the genetic diversity of Salvia fruticosa Mill. clones using RAPD markers and comparison with the essential oil profiles. Biochem Syst Ecol 27: 559-568

43. Singh M, Guleria N (2013) Influence of harvesting stage and inorganic and organic fertilizers on yield and oil composition of rosemary (Rosmarinus officinalis L.) in: a semi-arid tropical climate. Ind Crop Prod 42: 37-40.

44. Jordán MJ, Lax V, Rota MC, Lorán S, Sotomayor JA (2013) Effect of the phenological stage on the chemical composition, and antimicrobial and antioxidant properties of Rosmarinus officinalis $\mathrm{L}$. essential oil and its polyphenolic extract. Ind Crop Prod 48: 144-152.

45. Okoh OO, Sadimenko AP, Sadimenko AJA (2010) Comparative evaluation of the antibacterial activities of the essential oils of Rosmarinus officinalis L. obtained by hydrodistillation and solvent free microwave extraction methods. Food Chem 120: 308-312.

46. Hussain Al, Anwar F, Sherazi STH, Przybylski R (2008) Chemical composition, antioxidant and antimicrobial activities of basil (Ocimum basilicum) essential oils depends on seasonal variations. Food Chem 108: 986-995.

47. Chryssavgi G, Vassiliki P, Athanasios M, Kibouris T, Michael K (2008) Essential oil composition of Pistacialentiscus L. and Myrtuscommunis L.: evaluation of antioxidant capacity of methanolic extracts. Food Chem 107: 1120-1130.

48. Sikkema J, de Bont JA, Poolman B (1995) Mechanisms of membrane toxicity of hydrocarbons. Microbiol Rev 59: 201-222.

49. Cox SD, Mann CM, Markham JL, Bell HC, Gustafson JE, et al. (2000) The mode of antimicrobial action of the essential oil of Melaleuca alternifolia (tea tree oil). J Appl Microbiol 88: 170-175.

50. Magiatis P, Skaltsounis AL, Chinou I, Haroutounian SA (2002) Chemical composition and in-vitro antimicrobial activity of the essential oils of three Greek Achillea species. Z Naturforsch C 57: 287-290.

51. Tabanca N, Kirimer N, Demirci B, Demirci F, Başer KH (2001) Composition and antimicrobial activity of the essential oils of Micromeria cristata subsp. phrygia and the enantiomeric distribution of borneol. J Agric Food Chem 49: 4300-4303.
52. Santoyo S, Cavero S, Jaime L, Ibañez E, Señoráns FJ, et al. (2005) Chemical composition and antimicrobial activity of Rosmarinus officinalis L. essential oil obtained via supercritical fluid extraction. J Food Prot 68: 790-795.

53. Jiang Y, Wu N, Fu YJ, Wang W, Luo M, et al. (2011) Chemical composition and antimicrobial activity of the essential oil of Rosemary. Environ Toxicol Pharmacol 32: 63-68.

54. Tavassoli S, Djomeh ZE (2011) Total phenols, antioxidant potential and antimicrobial activity of methanol extract of rosemary (Rosmarinus officinalis L.). Glob Vet 7: 337-341.

55. Hummelbrunner LA, Isman MB (2001) Acute, sublethal, antifeedant, and synergistic effects of monoterpenoid essential oil compounds on the tobacco cutworm, Spodoptera litura (Lep., Noctuidae). J Agric Food Chem 49: 715-720.

56. Pavela R (2014) Acute, synergistic and antagonistic effects of some aromatic compounds on the Spodoptera littoralis Boisd.(Lep., Noctuidae) larvae. Ind Crops Prod 60: 247-258.

57. Nedorostova L, Kloucek P (2009) Antimicrobial properties of selected essential oils in vapour phase against foodborne bacteria. Food Control 20: 157-160.

58. Lambert PA (2002) Cellular impermeability and uptake of biocides and antibiotics in Gram-positive bacteria and mycobacteria. J Appl Microbiol 92 S46-S54.

59. Harris R (2003) Synergism in the essential oil world. The International Journal of Aromatherapy 12: 179-186.

60. Bezić N, Skocibusić M, Dunkić V, Radonić A (2003) Composition and antimicrobial activity of Achillea clavennae L. essential oil. Phytother Res 17 : 1037-1040.

61. Cowan MM (1999) Plant products as antimicrobial agents. Clin Microbiol Rev 12: $564-582$

62. Wendakoon CN, Sakaguchi M (1995) Inhibition of amino acid decarboxylase activity of Enterobacter aerogenes by active components in spices. Journal of Food Protection 58: 280-283.

63. Burt S (2004) Essential oils: their antibacterial properties and potential applications in foods--a review. Int J Food Microbiol 94: 223-253.

64. Skocibušic M, Bezic N, Dunkic V (2006) Phytochemical composition and antimicrobial activities of the essential oils from Satureja subspicata vis. growing in Croatia. Food Chem 96: 20-28.

65. Dellacassa E, Lorenzo D, Moyna P, Frizzo CD, Atti-Serafini L, et al. (1999) Rosmarinus officinalis L. (Labiatae) Essential Oils from the South of Brazil and Uruguay. JEOR 11: 27-30.

66. Duarte MC, Figueira GM, Sartoratto A, Rehder VL, Delarmelina C (2005) AntiCandida activity of Brazilian medicinal plants. J Ethnopharmacol 97: 305-311.

67. Hammer KA, Carson CF, Riley TV (1999) Antimicrobial activity of essential oils and other plant extracts. J Appl Microbiol 86: 985-990.

68. Ríos JL, Recio MC (2005) Medicinal plants and antimicrobial activity. J Ethnopharmacol 100: 80-84.

69. Bertini LM, Pereira AF, Oliveira CLL, Menezes EA, Morais SM, et al. (2005) Perfil de sensibilidade de bactériasfrente a óleosessenciais de algumas plantas do nordeste do Brasil. Infarma 17: 80-83.

70. Nascimento PFC, Nascimento AC, Rodrigues CS, Antoniolli AA, Santos PO, et al. (2007) Antimicrobial activity of the essentials oils: a multifactor approach of the methods. Rev. Bras. Farmacogn 17: 108-113.

71. Celiktas OY, Kocabas EEH, Bedir E, Sukan FV, Ozek T, et al. (2007) Antimicrobial activities of methanol extracts and essential oils of Rosmarinus officinalis, depending on location and seasonal variations. Food Chem 100: 553-559. 